\title{
Neuropathic Pain in Fabry Disease
}

\author{
Hande Türker ${ }^{1}$, Cetin Kursad Akpınar ${ }^{2 *}$ and Ayse Oytun Bayrak ${ }^{1}$ \\ ${ }^{1}$ Ondokuz Mayis University, Turkey \\ ${ }^{2}$ Samsun Training andResearchHospital, Neurology Clinic, Turkey
}

Submission: December 22, 2016; Published: February 15, 2017

*Corresponding author: Cetin Kursad Akpinar,Ondokuz Mayis University, Medical Faculty,Neurology, Samsun, Turkey, Tel: +90542 22626 05;

Email: dr_ckakpinar@hotmail.com

\begin{abstract}
Fabry Disease [FD] is an X-linkedly so somal storage disease caused by the mutations in the GLA gene codingforthelysosomalenzyme $\alpha$-galactosidase in chromosome Xq 22.1. Thediseaseleadstoaccumulation of neutralsphingolipids in tissues. About $80 \%$ of Fabry patients [FP] suffer from a painful neuropathy that usually begins in the first two decades. About $80 \%$ of FP suffer from a painful neuropathy. Enzymereplacementtherapies with recombinant human alpagalactosidase A is reported to improve small fiber neuropathy and neuropathic pain after 18-23 months of therapy. Enzymereplacementtherapies has positive effects on neuropathic pain in FD. Quality of life was decreased in Fabry males in the domains of physical functioning and bodily pain and of general health perception in females. Carbamazepine alone or in combination with pregabalin is recommended as first line treatment in neuropathic pain of FD. Neuropathicpaindiagnosis in Fabry patients deserves no reattention especially inadolescents and women with increasing diagnostic skills. We believe neuropathic pain of Fabry Disease will be diagnosed more frequently.
\end{abstract}

Keywords: Fabry disease, Enzyme replacement therapy, Neuropathic pain, Pregabalin

Abbreviations: ERT: Enzyme Replacement Therapy; FD: Fabry Disease; FP: Fabry Patients; MSSI: Mainz Severity Score Index; NP: Neuropathic pain

\section{Introduction}

Fabry Disease [FD] is an X-linkedly so somal storage disease caused by the mutations in the GLA gene coding for the lysosomal enzyme $\alpha$-galactosidase in chromosome Xq22.1 9 [1]. Thediseaseleadstoaccumulation of neutralsphingolipids in tissues. Undegraded glycosphingo lipids, especially globotriaosylceramide Gb3, accumulate mainly in the vascular endothelium and peripheral nervous system [1,2]. Neuropathic pain [NP] episodes are common both in childhood and adulthood. Neuropathic pain develops as a result of lesions or disease affecting the somato sensory nervous system either in the periphery or centrally.

Pain crises with sudden sharp pain in digits may be triggered by changes in skin temperature through cold, heat exposure or fever during infections [3]. Despite the cardinal presenting symptoms in childhood of acroparesthesias, pain crises, and angio keratomas, FD is often misdiagnosed or overlooked [4]. Clinically, small fiber dysfunction contributes to recurrent episodes of burning and lancinating pain and paresthesias in the distal extremities. Such episodes can be typically triggered by changes of the environmental temperature, particularly by warming [5].
About $80 \%$ of Fabry patients [FP] suffer from a painful neuropathy that usually begins in the first two decades [6]. The degree of the painful neuropathy can be characterized by the use of standardized pain scales [7]. Female heterozygote carriers of the genetic defect might also develop symptoms of the disease. Neuropathic pain of the female carriers corresponds to the pain reported by male patients and usually also occurs in the first two decades [8].

\section{Discussion}

The most significant emphasis on Fabry neuropathic pain is on childhood form of the disease and adult FD with neuropathic pain are usually under diagnosed especially in countries where awareness of FD is low. Although adult hood is known to reduce the burden of pain in FP, there are not any studies comparing the severity of pain in childhood with the severity in adulthood.

Chronic burning peripheral pain, attacks of acute excruciating peripheral pain and autonomic dysfunction should prompt the clinician to consider FD and to perform appropriate tests [7]. The burden of the progressive neurologic disease should be assessed early because neurologic disability in FD increases with age, both in males and females. 
The early neurologic manifestations of FD are initially often subtle and affected children are frequently misdiagnosed. Fatigue and emotional disturbances co-occur with Fabryrelated pain. While some patients report that their physicians understand them, others feel their physicians do not believe them and/or think they exaggerate the pain [9]. In a report of an expert panel in 2011, the authors suggested that a thorough physical examination [e.g., angiokeratomas, corneal opacities] and simple non-invasive sensory perception tests could provide clues to the diagnosis of FD [7].

The burden of disease in women can be substantial. For example the Mainz Severity Score Index [MSSI] shows that men and women experience a similar impact from FD $[8,9,10]$ and health related quality of life is similarly reduced in women and men with FD [11]. Without treatment, lifespan is typically reduced by 15 years in women with FD.

According to a cohort study of 36 women for 4 years, Brief Pain Inventory scores of the patients was reduced by ERT $[p=0.001]$ and remained reduced through four years $[1,12]$. It was concluded that long termagalsidase alpha was effective and well tolerated in women with FD.

Enzymereplacementtherapies with recombinant human alpagalactosidase $\mathrm{A}$ is reported to improve small fiber neuropathy and neuropathic pain after 18-23 months of therapy. The authors stated that this effect resulted from glycol sphingo lipid clearing from perineural cells, axons and Schwann cells or from blood vessels supplying the nerves. Enzymereplacementtherapies has positive effects on neuropathic pain in FD according to Schiffmann et al. [13]. They reported that FP participating in ERT could reduce their regular pain medications [14]. Dutsch et al. [5] performed quantitative sensory testing in FP under ERT [5].

Quantitative sensory tests are time consuming and are not widely used and popular among physicians who deal with FP most commonly. On the other hand, simple pain questionnaries targeting to diagnose the severity of neuropathic pain may be more user-friendly and practical.

Neuropathic pain affects quality of life in both men and women with FD [11,15]. Neuropathic pain interferes with both activities of daily living and quality of sleep at night, thus depression is often seen in these patients. Pain affects major daily functions of life.

Little is known on the impact of growing up with FD on psychosocial development [16]. Quality of life was decreased in Fabry males in the domains of physical functioning and bodily pain and of general health perception in females according to a study by Bouwman et al. [16]. They used Course of Life Questionnaire and the Short Form Health Survey [SF-36] in this study.

A validated disease severity scoring system for FD was suggested by Gianini et al. in 2010. Their study shows that the Fabry DS3 correlates highly with the clinical assessment by FD experts. It is obvious that validations of FDS3 should be performed in other countries where English is not the native language and thus validation studies will be needed and this may take time [17].

There is not a randomized controlled trial of an analgesic for the treatment of painful peripheral neuropathy in FD, only some empiric use of drugs has been reported [7]. Carbamazepine alone or in combination with pregabalin [rather than gabapentin] is recommended as first line treatment in neuropathic pain of FD. $[18,19,20]$. Antidepressants, particularly dual reuptake inhibitors of both serotonin and norepinephrine [SNRIs, venlafaxine, duloxetine] are also viable options although, tricyclic antidepressants have potential concomitant and difficult side-effects in FP [e.g accentuation of autonomic instability] $[7,18,19,20]$.

Although experts of pain recommend pain scales, they have not gained popularity among clinicians who deal with Fabry disease mostly. One of the reasons for this observation may be the difficulty of usage in the pediatric population. Nevertheless we should not forget that there are adult patients having NP, thus simple diagnostic scales like DN4 may be practical to use in clinical routine. A neuropathy pain assessment scale should be used at the initial assessment and follow up examinations.

\section{Conclusion}

Neuropathic pain diagnosis in Fabry patients deserves more attention especially in adolescents and women with increasing diagnostic skills and we believe neuropathic pain of Fabry Disease will be diagnosed more frequently and thus we need more studies involving Fabry neuropathic pain.

\section{References}

1. Desnick R, Ioannou Y, Eng C (2001) Alpha-Galactosidase A deficiency: Fabrydisease. In: Scriver CR BA, Sly WS, et al. (Eds.), (8th edn), NY: McGraw-Hill; 3733-3774, New York, USA.

2. Franceschi F, Gigante G, Roccarina D, Vitale G, Ainora ME, et al. (2008) Fabry disease and small intestinal bacterial over growth: prevalence andcorrelation with gastro intestinal symptoms. Digestive and Liver Disease 40(Suppl 3): S143-S144.

3. Mac Dermot J, Mac Dermot KD (2001) Neuropathicpain in AndersonFabrydisease: pathology and therapeutic options. Europ J Pharma 429(1-3): 121-125.

4. Desnick R, Brady R (2004) Fabrydisease in childhood. J Pediatr 144(5 suppl): S20-S26.

5. Dütsch M, Hilz MJ (2010) Neurological complications in Fabrydisease. RevMedInterne 31 (Suppl 2): S243-S250.

6. MaagR,BinderA,BaronR(2008)AssessmentofPainandSomatosensoryFunction in FabryDisease: Early Diagnosis. ClinTher 30: S52-S53.

7. Burlina AP, Sims KB, Politei JM, Bennett GJ, Baron R, et al. (2011) Early diagnosis of peripheral nervous system involvement in Fabry disease and treatment of neuropathic pain: the report of an expert panel. BMC Neurol 11: 61 .

8. Laaksonen SM, Roytta M, Satu KJ, Kantola I, Penttinen M, et al. (2008) Neuropathic symptoms and findings in women with Fabry disease. Clin Neurophysiol 119(6):1365-1372. 
9. Schaik IV, Hollak CEM (2013) Fabry Disease: A Rare Cause of Neuropathic Pain. Curr Pain Headache Rep17(10): 365.

10. Weidemann F, Krämer J, Duning T, Lenders M, Canaan-Kühl S, et al. (2014). Patients with Fabry disease after enzyme replacement therapy dose reduction versus treatment switch. J Am Soc Nephrol 25(4): 837849.

11. Gold KF, Pastores GM, Botteman MF, Yeh JM, Sweeney S, et al. (2002) Quality of life of patients with Fabry disease. Qual Life Res 11(4): 317327.

12. Whybra C, Miebach E, Mengel E, Gal A, Baron K, et al. (2009) A 4-year study of the efficacy and tolerability of enzyme replacement therapy with agalsidase alfa in 36 women with Fabry disease. Genet Med 11(6): 441-449.

13. Schiffmann R, Moore DF (2006) Neurological manifestations of Fabry disease. In: Mehta A, Beck M, Sunder-Plassmann G (Eds.), Fabry Disease: Perspectives from 5 Years of FOS. Oxford: Oxford Pharma Genesis, p. 22.

14. Hilz MJ, Brys M, Marthol H, Stemper B, Dütsch M (2004) Enzyme replacement therapy improves function of $\mathrm{C}_{-}$, A delta-, and Abetanerve fibers in Fabry neuropathy. Neurology13 62(7): 1066-1072.
15. Watt T, Burlina AP, Cazzorla C, Schönfeld D, Maryam Banikazemi, et al. (2010) Agalsidase beta treatment is associated with improved quality of life in patients with Fabry disease: findings from the Fabry Registry. Genet Med 12(11): 703-712.

16. Bouwman MG, Maurice-Stam H, Linthorst GE, Hollak CE, Wijburg FA, et al. (2011) Impact of growing up with Fabry disease on achievement of psychosocial milestones and quality of life. Mol Genet Metab 104(3): 308-313.

17. Giannini EH, Mehta AB, Hilz MJ, Beck M, Bichet DG, et al. (2010) A validated disease severity scoring system for Fabry disease. Mol Genet Metab 99(3): 283-290.

18. Sommer C, Uceyler N, Duning T, Arning K, Baron R, et al. (2013) Pain therapy for Fabry's disease. Internist (Berl) 54(1): 121-122.

19. Ries M, Mengel E, Kutschke G, Kim KS, Birklein F, et al. (2003) Use of gabapentinto reduce chronic neuro pathic pain in Fabry disease. J Inherit Metab Dis 26(4): 413-414.

20. Linthorst GE, Germain DP, Hollak CEM, Hughes D, Rolfs A, et al. (2011) Expert opinion on temporary treatment recommendations for Fabry disease during the shortage of enzyme replacement therapy (ERT). Mol Genet Metab 102(1): 99-102.

\section{Your next submission with Juniper Publishers will reach you the below assets}

- Quality Editorial service

- Swift Peer Review

- Reprints availability

- E-prints Service

- Manuscript Podcast for convenient understanding

- Global attainment for your research

- Manuscript accessibility in different formats

( Pdf, E-pub, Full Text, Audio)

- Unceasing customer service

Track the below URL for one-step submission https://juniperpublishers.com/online-submission.php 